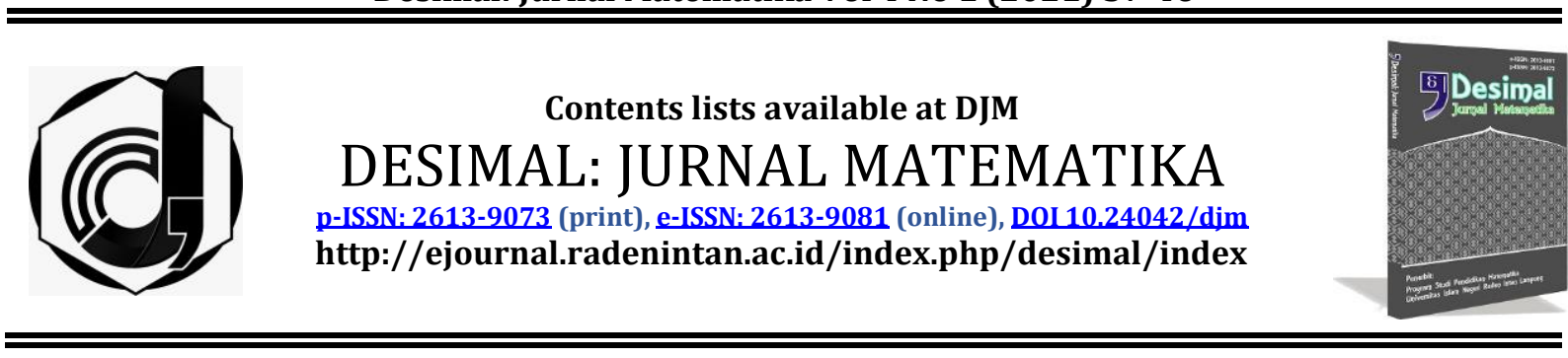

\title{
Structural equation modeling-partial least squares: Analysis of the effect of hedonic value on customer satisfaction and loyalty
}

\author{
Vivi Iswanti Nursyirwan*, Nina Valentika \\ Pamulang University, Indonesia
}

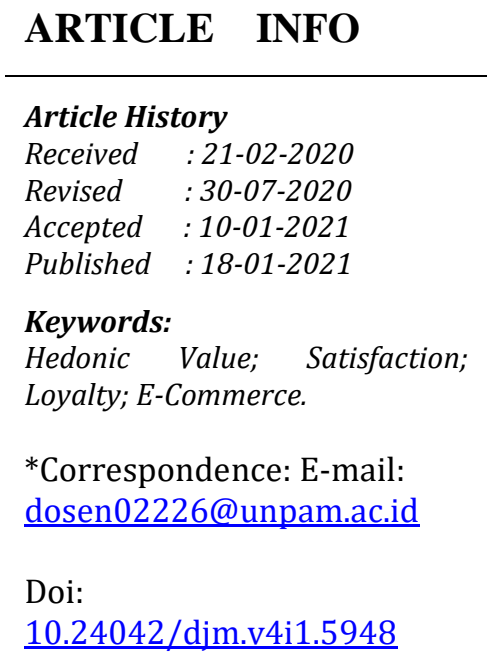

\begin{abstract}
Testing the effect of hedonic value on loyalty, the hedonic value on satisfaction, and customer satisfaction on consumer loyalty, and investigating the effect of hedonic value on consumer loyalty with customer satisfaction as an intervening variable is the purpose of this study, with a case study on e-commerce Shopee. The sample aims to be a method of determining the sample with a total of 100 respondents. The intended respondents are Pamulang University students, Faculty of Economics, S1 Accounting Department as well as consumers of Shopee e-commerce. The Research model used SEM-PLS Structural Equation Modeling-Partial Least Square Approach. The results of this study indicate that the hedonic value has a positive influence and also has a significant value on consumer loyalty at the real level of $10 \%$. The results of the study also state hedonic value has a significant positive effect on consumer satisfaction, and customer satisfaction has a significant positive effect on consumer loyalty with the satisfaction of consumer as a variable of intervening with $10 \%$ level.
\end{abstract}

http://ejournal.radenintan.ac.id/index.php/desimal/index

\section{INTRODUCTION}

E-Commerce is a place as a means available to both buy and sell products, services, and information through online facilities, internet facilities, and others. Shopee is one of the e-commerce companies from Singapore that has managed to maintain its leading position in top e-commerce for ten consecutive quarters, based on play-store ranking (iprice.co.id). Likewise, in the second quarter of 2019, Shopee led the app-store ranking again. However, when referring to the average number of visitors each month, Shopee was defeated by Tokopedia e-Commerce. The Tokopedia site receives 140.4 million visitors every month, in contrast to Shopee's only 90.7 million.

The internet is a computer network that is currently growing rapidly from a variety of business interests, education, to the government network that can be interconnected with each other, wherewith the number of users can 
develop more than 200 countries (O'Brien, 2003).

Consumer loyalty is something that is needed by the company. There are six reasons for the need for customer loyalty (Kotler et al., 2002), including: (1). Initial customers are more perspective, it means that loyal customers will generate large profits for the organization. (2). The costs of acquiring new customers are much higher than the costs of retaining existing customers. (3). Customers who already trust the company in one business tend to trust other businesses. (4). Cost efficiency is more efficient if customers are loyal. (5). Psychological costs and social costs are reduced because existing customers have many positive experiences with the company and with the company's products/services. (6). Loyal customers will always defend the company and even tend to attract and provide advice to others to become customers.

Customer satisfaction is one of the secrets to the success of a business. According to Agag \& El-Masry (2016) satisfaction is assessed as a comparison of post-purchase with pre-purchase expectations and the performance received.

According to Sharma \& Wang (2015) in the context of e-commerce is described in the attitude and expectations of users who have received good service when using the application to create visiting behavior and repurchase interest. One of the factors causing satisfaction in ecommerce lies in the value perceived by the user, such as hedonic values. Hedonic value is the benefit of the overall assessment of experience and sacrifice. Customers are satisfied when making a transaction supported by the effectiveness in responding to user responses and user convenience when searching.

\section{Loyalty}

The loyalty of the consumer is a firmly held commitment to repurchasing or repatriating a preferred product or service in the future even though situational influences and marketing efforts have the potential to lead to shifting behavior (Kotler \& Keller, 2012).

Griffin (2005) states that there are four characteristics of loyal customers, including 1). Repurchasing (2). Recommending products/services to other parties, (3). Not being influenced by competitors and (4). Buying the same product on the same channel.

Six (6) indicators of customer loyalty according to Roberts et al. (2003), including: (1). There is a desire to share information (2). Provide an explanation of positive values to other people/parties (3). Recommending products/services to other parties/people (4). Make a repurchase (5). Making additional purchases of products/services (6). Testing new services.

\section{Satisfaction}

According to Yeh \& Li (2009), satisfaction is an evaluation process and the formation of post-purchase comparisons. The satisfaction level is part of an important factor when online shopping. The level of satisfaction is obtained from the feelings of pleasure, disappointment after a comparison between one's expectations and the performance of a product. Pleasure is also assessed as an experience that customers get (Chinomona et al., 2014). Suki (2012) states satisfaction is obtained from affective attitude on the results of an evaluation of consumers.

\section{Hedonic Value}

Perceived value is part of the assessment of customer's perceptions and experiences on the products and services (Chinomona et al., 2014). It plays an important role in increasing re-purchase customers and becomes attractive to be analyzed (Hu \& Chuang, 2012). Perceived 
value means the overall value received and given to products and services by customers (Lexhagen, 2008). In the previous research by Wu \& Chang (2016), perceived value considered as something to be felt and evaluated on that ecommerce.

Babin et al. (1994) state that consumers are often shopping for an appreciation of their experience, not just completing a task. The various dimensions of hedonic value from various literature have been extensively investigated inshop shopping (Babin et al., 1994); (Darden \& Reynolds, 1971); (Overby \& Lee, 2006); (Yoo et al., 2010), and it has been recognized that it is an important component in online shopping (Burke, 1999).

E-commerce where hedonic value has an influence on satisfaction and this is supported by interactive relationships both in terms of providers and purchases, making customers often experience deep relationships that make e-commerce users happier (Yoo et al., 2010).

\section{Hypothesis:}

$\mathrm{H}_{1}$ : It is assumed that hedonic value has a significant positive effect on consumer loyalty in Shopee's e-commerce.

$\mathrm{H}_{2}$ : It is assumed that hedonic value has a significant positive effect on customer satisfaction of Shopee e-commerce.

$\mathrm{H}_{3}$ : It is assumed the satisfaction of consumers has a significant positive effect on the loyalty of consumers of Shopee's ecommerce.

$\mathrm{H}_{4}$ : It is assumed that hedonic value has a significant positive effect on the loyalty of consumers with the satisfaction of consumers as an intervening variable. 
Desimal, 4 (1), 2021 - 40

Vivi Iswanti Nursyirwan, Nina Valentika

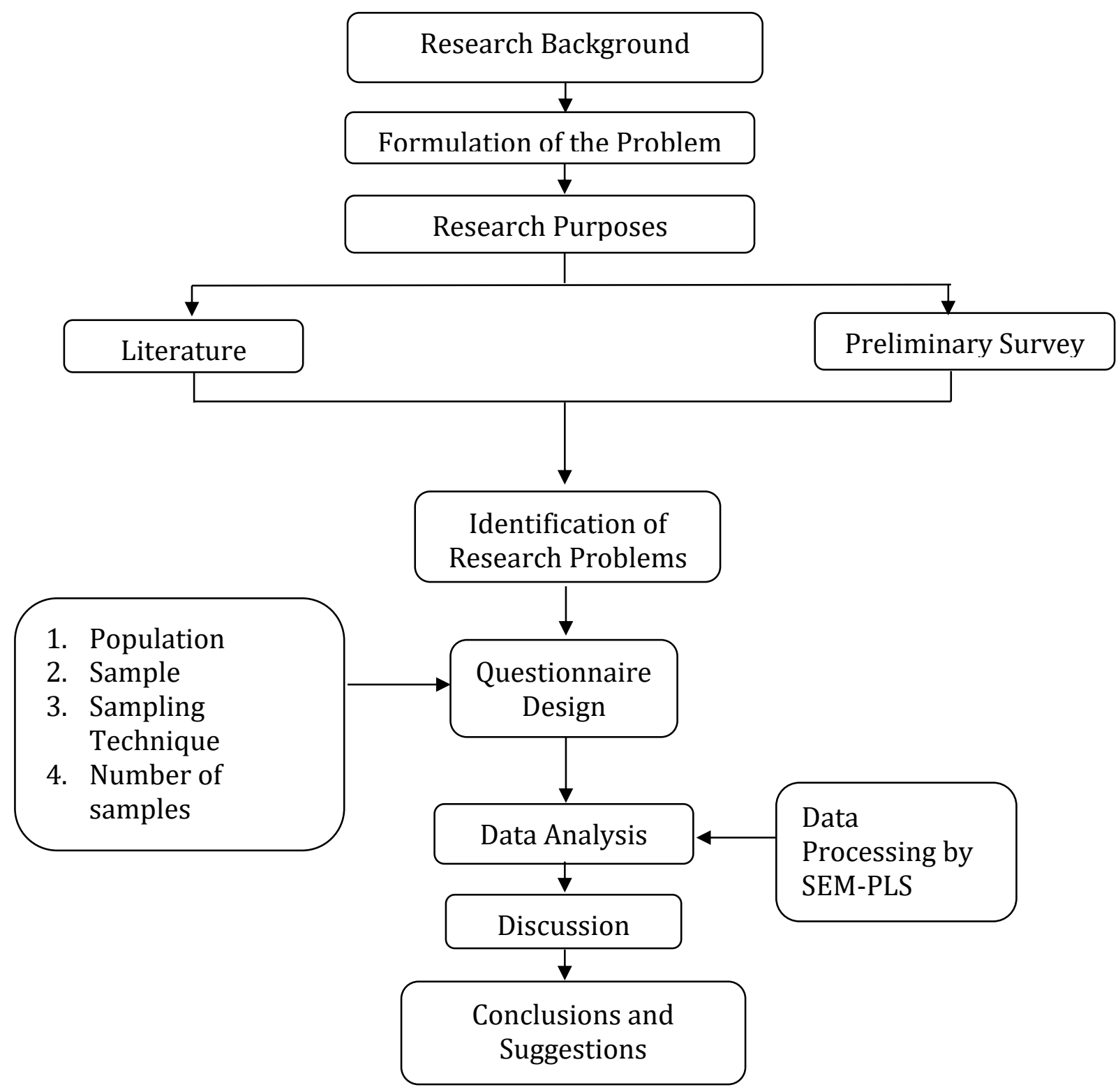

Figure 1. Research Flow Chart

Herewith the conceptual framework of this study as shown in Figure 2.

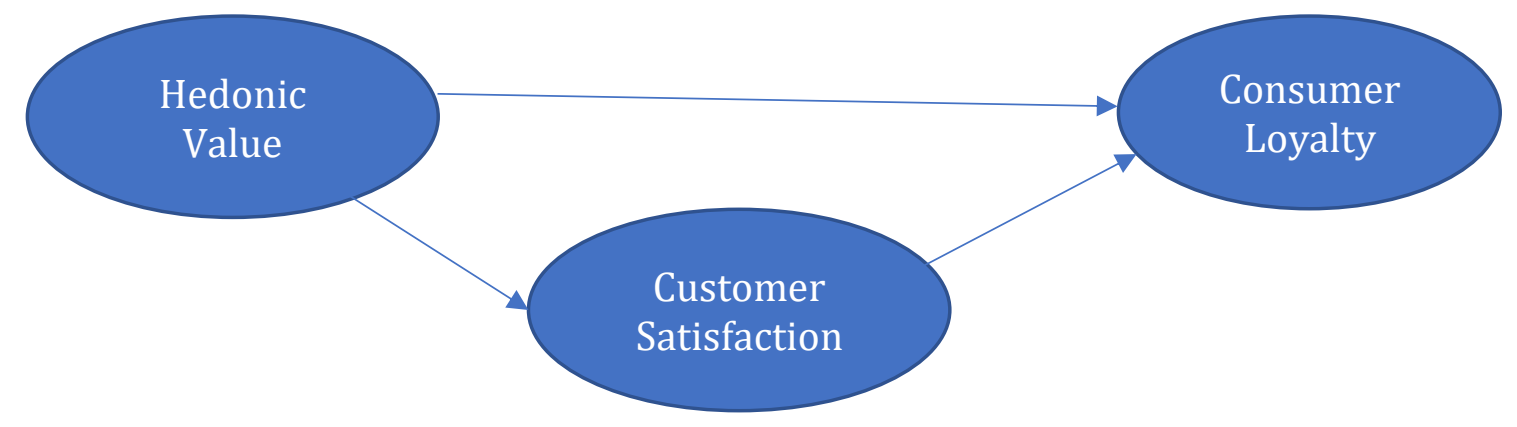

Figure 2. Conceptual Framework 
Desimal, 4 (1), 2021 - 41

Vivi Iswanti Nursyirwan, Nina Valentika

\section{METHOD}

\section{The Data Collection Techniques}

Association research is an approach to this research, namely research that aims to determine the relationship or influence between two or more variables.

\section{Sample Collection Techniques}

Visitors to the Shopee online shop in Indonesia in 2019 are the population of this study. The data that is the source of the research is primary data, with the process of distributing questionnaires online. The research sample used the concept of cluster random sampling. While the sample criteria are those Shopee consumers who are also Economics students majoring in Accounting at Pamulang University who have at least had the experience of shopping at least once at Shopee E-Commerce.

Determination of the number of samples using an error rate of $10 \%$ and the calculation of the Slovin formula, as follows:

$$
\begin{aligned}
n & =\frac{N}{1+N(k)^{2}} \\
& =\frac{90.7 \times 10^{6}}{1+90.7 \times 10^{6}(10 \%)^{2}} \\
& =99.99988975 \approx 100
\end{aligned}
$$

Remarks:

$N \quad$ : the population amount $(90.7$ million Shopee visitors in Indonesia on 2019)

$k$ : error rate $=10 \%$

$n$ : the total of research samples

\section{Data Analysis Method}

In this study, the data analysis method is an outer model consisting of convergent validity and reliability data, followed by an inner model and hypothesis test. Furthermore, this study uses Structural Equation Modeling with the use of Smart PLS software version 3.

Calculation of the value of Composite reliability (CR) and Average Variance
Extracted (AVE) can be done by using the following formula:

$$
\rho_{c}=\frac{\left(\sum \lambda_{i}\right)^{2} \operatorname{var} F}{\left(\sum \lambda_{i}\right)^{2} \operatorname{var} F+\sum \Theta_{i i}}
$$

Where:

$\lambda_{i}:$ loading factor

$F$ : variance of factor

$\Theta_{i i}$ : variance of error

$$
A V E=\frac{\left(\sum \lambda_{i}^{2}\right) \operatorname{var} F}{\left(\sum \lambda_{i}^{2}\right) \operatorname{var} F+\sum \Theta_{i i}}
$$

Where:

$\lambda_{i}:$ loading factor

$F \quad$ : variance of factor

$\Theta_{i i}$ : variance of error

\section{OUTPUT SESSION}

Initial data were processed using the Structural Equation Model-Partial Least Square (SEM-PLS) approach.

The Smart PLS version 3 application is used in the data processing in this study. After the respondent fills in the questionnaire data, the tabulated data that has been programmed in Smart PLS is processed, made in the form of a model, loading factor, the significance of each latent variable is identified.

\section{Running SEM-PLS Stage 1}

In the first test, it appears that the loading value of the indicator there are still a few that are under the terms of validity of 0.70 . Generally, the loading value below 0.70 is better removed from the model line to increase validity and reliability.

\section{Running SEM-PLS Stage 2}

After running of 2, loading values $>$ 0.70 are obtained for all indicators. Average variance extracted (AVE) has a requirement $>0.5$. From Figure 2, AVE values include a hedonic value which is 
Desimal, 4 (1), 2021 - 42

Vivi Iswanti Nursyirwan, Nina Valentika

0.683 , Consumer loyalty of 0.641 , and Customer Satisfaction of 0.728 .

From Figure 3, Composite reliability (CR) value is said to be reliable if it has a Construct Reliability and Validity

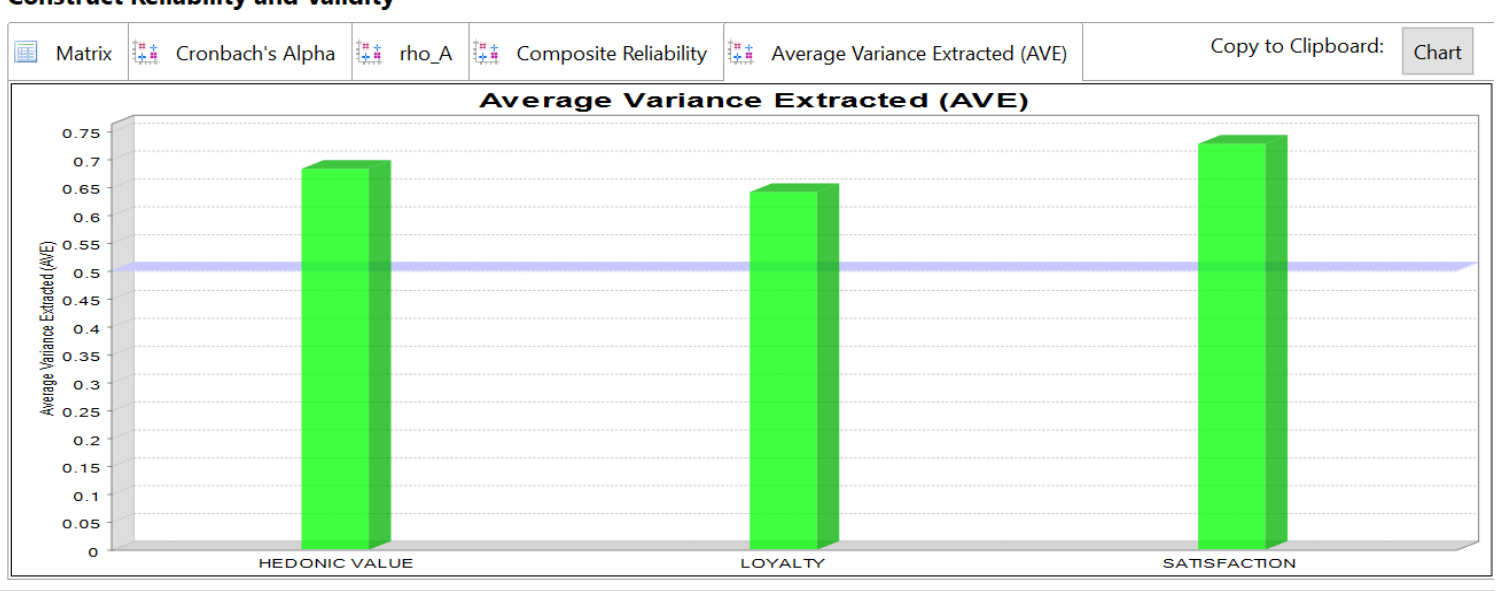

Figure 3. Average Variance Extracted

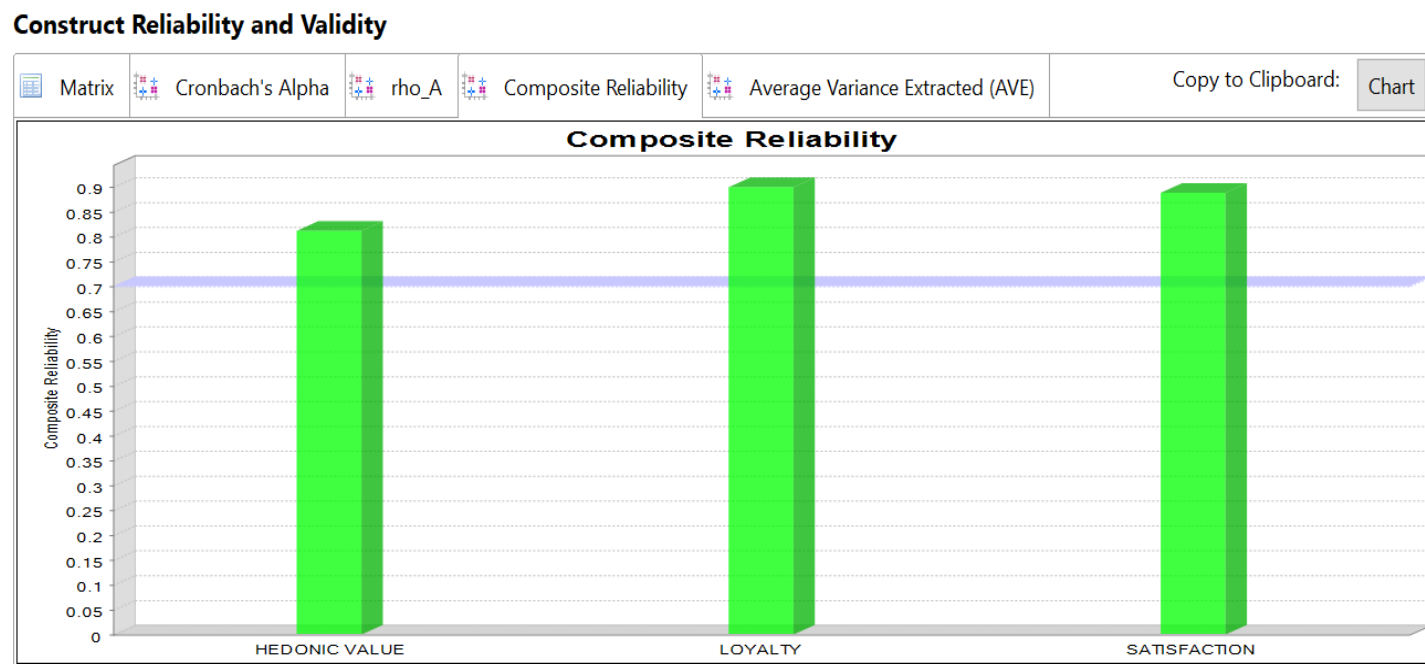

Figure 4. Composite Reliability

\section{The Outcome of Measurement Model} (Outer Model)

The indicator is declared valid if it has a loading value $>$ If the loading factor is $>0.7$ on an indicator of the intended construct, and has more value than cross- number of each variable is 0.812 for hedonic value, consumer loyalty of 0.899 , and customer satisfaction of 0.888 . 
Desimal, 4 (1), 2021 - 43

Vivi Iswanti Nursyirwan, Nina Valentika

Table 1. Cross Loadings

\begin{tabular}{llll}
\hline & Hedonic & Loyalty & Satisfaction \\
$\mathrm{X} 4.4$ & 0.815 & 0.624 & 0.348 \\
$\mathrm{X} 4.1$ & 0.838 & 0.550 & 0.518 \\
$\mathrm{Y} 2.1$ & 0.590 & 0.777 & 0.381 \\
$\mathrm{Y} 2.3$ & 0.538 & 0.807 & 0.447 \\
$\mathrm{Y} 2.4$ & 0.512 & 0.775 & 0.444 \\
$\mathrm{Y} 2.5$ & 0.605 & 0.859 & 0.498 \\
$\mathrm{Y} 2.6$ & 0.588 & 0.783 & 0.308 \\
$\mathrm{Y} 1.1$ & 0.434 & 0.477 & 0.907 \\
$\mathrm{Y} 1.2$ & 0.477 & 0.478 & 0.916 \\
$\mathrm{Y} 1.3$ & 0.436 & 0.368 & 0.722 \\
\hline
\end{tabular}

\section{Structural Model Results (Inner Model)}

In the literature presented by Hair in (Ghozali \& Latan, 2012), the model is said to be strong if it has an $R 2$ value $>0.75$, it is said to be a moderate model if the $R 2$ value is $>0.5$ and the model is weak if it has an $\mathrm{R} 2$ value $>0.25$. In Figure 4 it is known the acquisition value $\mathrm{R} 2=0.532$ for customer loyalty. This figure shows that the variable customer loyalty can be explained by the construct (hedonic and satisfaction of customer) of $53.2 \%$. Meanwhile, the figure of $46.8 \%$ is defined by another variable outside the research model. For the value of R2 on the satisfaction variable $=0.277$. It means that customer satisfaction can be explained by the construct (hedonic) of = $27.7 \%$, and it means that there are $72.3 \%$ remaining outside the research model.

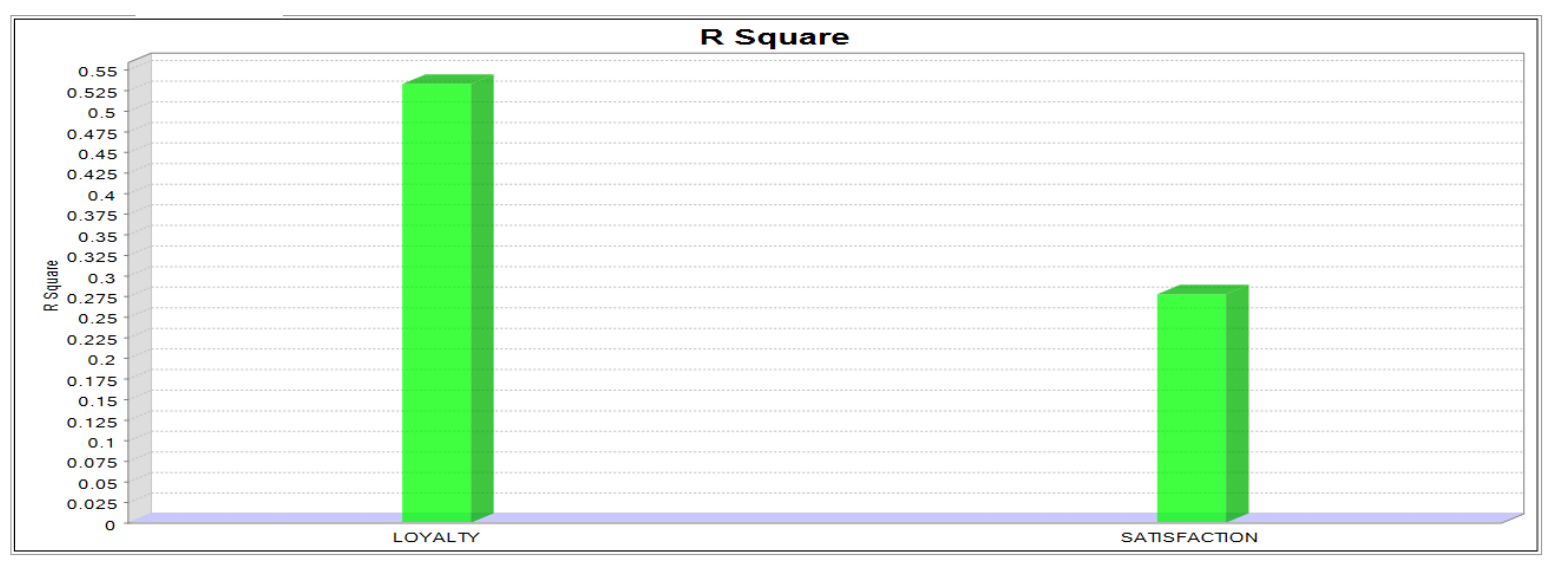

Figure 5. R Square Model

PLS model evaluation can also be done with the predictive relevance $Q^{2}$ value, in addition to seeing the magnitude of the $\mathrm{R}^{2}$ value. This approach uses a blindfolding procedure (Ghozali \& Latan, 2012), which was adapted by PLS. In Table
2 , the value of $Q^{2}$. As much as 0.312 on the customer loyalty variable and 0.186 on the customer satisfaction variable. A value of $\mathrm{Q}^{2}>0$ means that this research model has predictive relevance.

Table 2. Q Predictive Relevance

\begin{tabular}{llll}
\hline Variable & SSO & SSE & $\mathbf{Q}^{2}$ \\
Hedonic & 200.000 & 200.000 & \\
Consumer Loyalty & 500.000 & 344.001 & 0.312 \\
Customer Satisfaction & 300.000 & 244.147 & 0.186 \\
\hline
\end{tabular}


It is necessary to carry out a bootstrap procedure in measuring the significance of the research model. Table 3 explains the path coefficient in the research model with a significance of $\alpha=$ $10 \%$. Figure 5 shows the bootstrap results of the research model.

Table 3. Path Coefficient

\begin{tabular}{|c|c|c|c|c|c|}
\hline Variable & $\begin{array}{l}\text { Original } \\
\text { Sample }\end{array}$ & $\begin{array}{l}\text { Sample } \\
\text { Mean }\end{array}$ & $\begin{array}{l}\text { Standard } \\
\text { Error }\end{array}$ & T Statistics & $\begin{array}{l}\mathbf{P} \\
\text { Values }\end{array}$ \\
\hline Hedonic Values--> Consumer Loyalty & 0.602 & 0.604 & 0.064 & 9.469 & 0.000 \\
\hline $\begin{array}{l}\text { Value of Hedonic-->Satisfaction of } \\
\text { consumer }\end{array}$ & 0.527 & 0.538 & 0.089 & 5.924 & 0.000 \\
\hline $\begin{array}{l}\text { Satisfaction of consumer--> Consumer } \\
\text { Loyalty }\end{array}$ & 0.203 & 0.208 & 0.072 & 2.838 & 0.002 \\
\hline $\begin{array}{l}\text { Value of Hedonic-->Consumer Loyalty } \\
\text { (with Customer Satisfaction as } \\
\text { Intervening Variables) }\end{array}$ & 0.107 & 0.111 & 0.042 & 2.535 & 0.006 \\
\hline
\end{tabular}

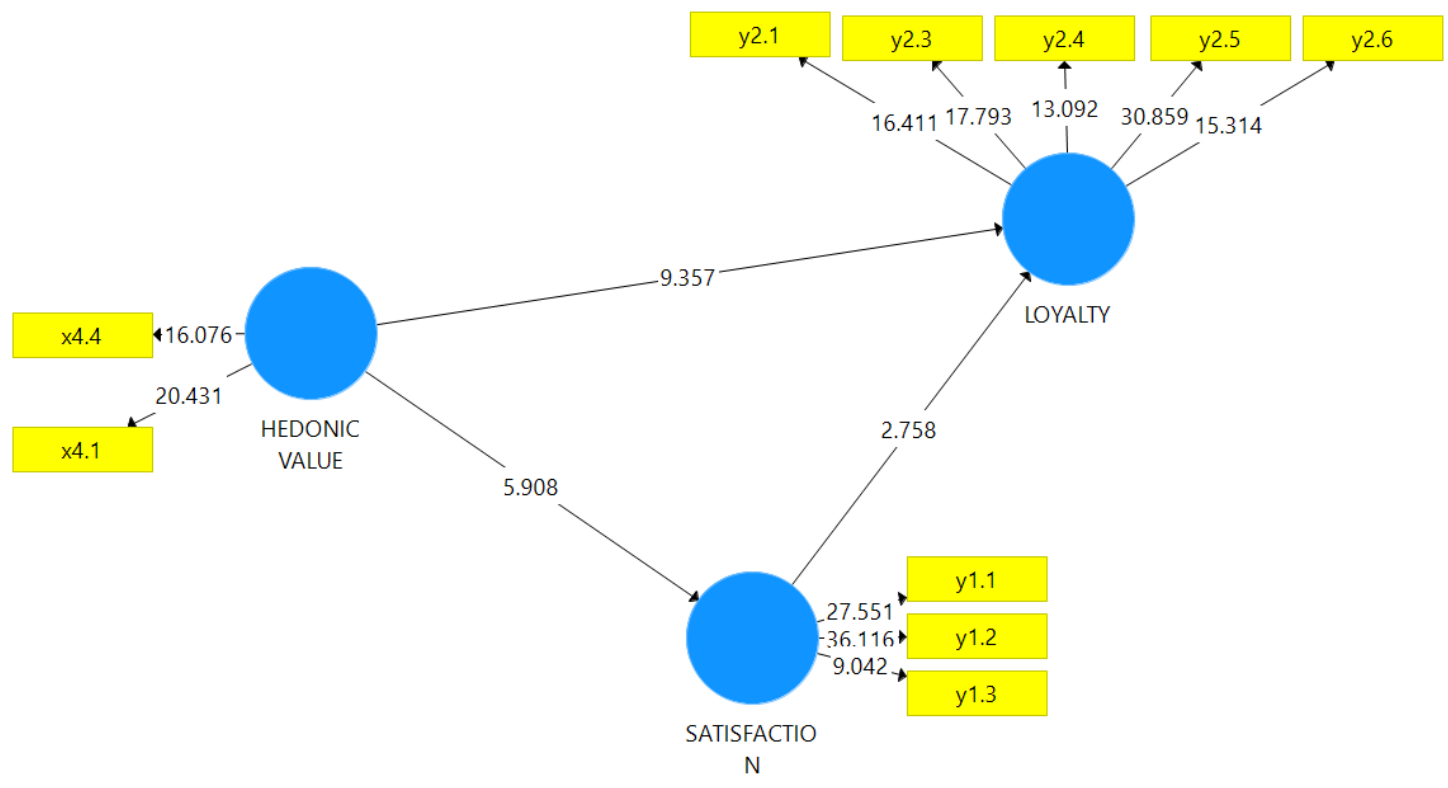

Figure 6. Bootstrapping Results

Hypothesis:

Hedonic value has a significant positive effect on consumer loyalty in Shopee's e-commerce

The rate of T-statistic of $9.469>1.64$ with significance $\alpha=0.1(10 \%)$ is the result of the path coefficient obtained between the hedonic value variables on consumer loyalty. This means that there is a significant positive influence between hedonic value on consumer loyalty. This shows that the higher the positive parameter coefficient on the hedonic value, consumer loyalty will also increase.
The results of this study indicate that $\mathrm{H} 1=$ accepted because the hedonic value has a positive and significant influence on consumer loyalty.

\section{Hedonic value has a significant positive effect on customer satisfaction of Shopee e-commerce}

The rate of T-statistic of 5.924> 1.64 with significance $\alpha=0.1(10 \%)$ is the result of the path coefficient obtained between the value of hedonic on the satisfaction of the customer. It can be stated that there is a positive influence 
with a significant value between the hedonic value on customer satisfaction. The value on the positive parameter coefficient shows the higher the hedonic value, the customer satisfaction will increase. The results of this study concluded that $\mathrm{H} 2$ = accepted because Hedonic value has a positive effect and significant on the satisfaction of consumers.

\section{The satisfaction of consumers has a significant positive effect on the loyalty of consumers of Shopee's e- commerce}

The rate of T-statistic of 2.838> 1.64 with significance $\alpha=0.1(10 \%)$ is the result of the path coefficient on the variable customer satisfaction on customer loyalty. This indicates that there is a positive influence with a significant value between the variable customer satisfaction and customer loyalty. A positive value on the parameter coefficient shows what if the higher the customer satisfaction, the higher the consumer loyalty is formed.

The results of this study concluded that $\mathrm{H} 3=$ accepted because the satisfaction of consumers has a positive influence with a significant value on consumer loyalty.

\section{Hedonic value has a significant positive effect on the loyalty of consumers with the satisfaction of consumers as an intervening variable}

The rate of T-statistic of 2.535> 1.64 with significance $\alpha=0.1(10 \%)$ is the result of the path coefficient obtained between the hedonic value variables on consumer loyalty. This means, there is a positive and significant influence between the hedonic value variable on the loyalty of consumers and the satisfaction of consumers as an intervening variable. The results of this study indicate that $\mathrm{H} 4$ is accepted because the hedonic value has a positive influence with a significant value on customer loyalty through the intervening variable customer satisfaction.

\section{CONCLUSIONS AND SUGGESTIONS}

In this study it can be explained that there is an effect of the relationship between exogenous latent variables on endogenous latent variables with the results of the research that the path coefficient of the hedonic value variable on consumer loyalty with a significance level of $=0.1(10 \%)$ indicates that there is a significant influence between the hedonic value on consumer loyalty. The path coefficient on the hedonic value variable on customer satisfaction at the significance level $=0.1(10 \%)$ that there is a significant influence between the hedonic value on customer satisfaction. The path coefficient results obtained between the variable customer satisfaction and customer loyalty at a significance level $=0.1(10 \%)$, it can be seen that there is a positive influence with a significant value between the variable customer satisfaction on customer loyalty. The path coefficient value is obtained between the value of the hedonic variable on consumer loyalty with a significance level of $=0.1(10 \%)$, it is concluded that there is a significant effect between the hedonic value on customer loyalty and customer satisfaction as an intervening variable. The next research should examine the influence of a larger sample and different case studies, replicate this research by adding other variables in identifying customer satisfaction and customer loyalty, using a larger sample, both in terms of geography, demography, etc., further research can use several examples of e-commerce besides Shopee, as well as using a comparative approach between e-commerce so that research results can be seen from the level of comparison of consumer satisfaction and loyalty clearly and can be generalized. 


\section{REFERENCES}

Agag, G. M., \& El-Masry, A. A. (2016). Cultural and religiosity drivers and satisfaction outcomes of consumer perceived deception in online shopping. Internet Research, 26(4), 942-965.

Babin, B. J., Darden, W. R., \& Griffin, M. (1994). Work and/or fun: Measuring hedonic and utilitarian shopping value. Journal of Consumer Research, 20(4), 644-656.

Burke, K. (1999). Creating a compelling online experience. CatAge, 16, 109.

Chinomona, R., Masinge, G., \& Sandada, M. (2014). The influence of e-service quality on customer perceived value, costumer satisfaction and loyalty in south africa. Mediterranean Journal of Social Sciences, 5(9).

Darden, W. R., \& Reynolds, F. D. (1971). Shopping orientations and product usage rates. Journal Marketing Research, 8, 505-508.

Ghozali, I., \& Latan, H. (2012). Partial least square: Konsep, teknik dan aplikasi SmartPLS 2.0 M3. Undip.

Griffin, J. (2005). Costumer loyalty: Menumbuhkan \& mempertahankan kesetiaan pelanggan. Erlangga.

Hu, F., \& Chuang, C. C. (2012). Study of the relationship between the value perception and loyalty intention toward an e-retailer website. Journal of Internet Banking and Commerce, 17(1).

Kotler, P., Hayes, T., \& Bloom, P. N. (2002). Marketing professional service. Prentice Hall Press.

Kotler, P., \& Keller, K. L. (2012). Manajemen Pemasaran (Edisi 1). Erlangga.

Lexhagen, M. (2008). Customer perceived value of travel and tourism websites.
European Tourism Research Institute, 2.

O'Brien, J. A. (2003). Introduction to information system: Essentials for the e-business enterprise (11th Ed). McGraw Hill Inc.

Overby, J. W., \& Lee, E. J. (2006). The effects of utilitarian and hedonic online shopping value on consumer preference and intentions. Journal of Business Research, 59, 1160-1166.

Roberts, K., Varki, S., \& Brodie, R. (2003). Measuring the quality of relationshop in customer services: An empirical study. European Journal of Marketing, 37(1/2), 169-196.

Sharma, G., \& Wang, L. (2015). The effects of online service quality of ecommerce websites on user satisfaction. The Electronic Library, 33(3), 468-485.

Suki, N. M. (2012). Examining factors influencing customer satisfaction and trust towards vendors on the mobile internet. Journal of Internet Banking and Commerce, 17(1).

Wu, J.-F., \& Chang, Y. P. (2016). Multichannel integration quality, online perceived value and online purchase intention: A perspective of land-based retailers. Internet Research, 26(5), 1228-1248.

Yeh, Y. S., \& Li, Y.-M. (2009). Building trust in m-commerce: Contributions from quality and satisfaction. Online Information Review, 33(6), 10661086.

Yoo, W. S., Yunjung, L., \& Jung, K. P. (2010). The role of interactivity in e-tailing: Creating value and increasing satisfaction. Journal of Retailing and Consumer Services, 17, 89-96. 